\title{
Role of lipid in the life cycles of ice-dependent and ice-independent populations of the copepod Paralabidocera antarctica
}

\author{
K. M. Swadling ${ }^{1, *}$, P. D. Nichols ${ }^{2,3}$, J. A. E. Gibson ${ }^{4}$, D. A. Ritz ${ }^{1}$ \\ ${ }^{1}$ School of Zoology, University of Tasmania, GPO Box 252-5, Hobart, Tasmania 7001, Australia \\ ${ }^{2}$ CSIRO Marine Research, GPO Box 1538, Hobart, Tasmania 7001, Australia \\ ${ }^{3}$ Antarctic CRC, GPO Box 252-80, Hobart, Tasmania 7001, Australia \\ ${ }^{4}$ Australian Antarctic Division, Channel Highway, Kingston, Tasmania 7050, Australia
}

\begin{abstract}
We compared the lipid stores of coastal and lacustrine populations of the copepod Paralabidocera antarctica over a complete developmental cycle. The life cycle of the coastal population, which was reflected in their pattern of lipid storage, was coupled closely to the growth of sea ice. Nauplii entered the sea ice in early autumn and overwintered predominantly as the NIV stage, with triacylglycerol comprising up to $26 \%$ of their dry weight (DW). During their rapid development from stages CI to CIV, much smaller quantities ( $<2 \%$ DW) of triacylglycerol were present. The population underwent a habitat shift from the ice to the water column at the CIV stage, although adults remained close to the ice-water interface. Adults of both sexes initially contained high amounts of triacylglycerol as a proportion of their total lipid (50\% in males, $65 \%$ in females), but these stores were depleted over the 3 wk-long period of mating and spawning. The lacustrine population of $P$. antarctica also accumulated triacylglycerol; however, their life cycle was largely independent of the ice cover on the lake. The CI to CIV stages of the lacustrine population contained more triacylglycerol than the same stages at the coastal site, suggesting that either they experienced short-term periods of starvation due to patchiness in the food supply or that their dietary intake was lipid-rich. Reproduction began 1 mo earlier in the lake population, and the lipid storage patterns of adults indicated a longer reproductive duration. The fatty acid composition of $P$. antarctica reflected that of particulate matter in the 2 environments, arguing for a relatively simple biochemical pathway in comparison to some of the larger pelagic copepods.
\end{abstract}

KEY WORDS: Triacylglycerol $\cdot$ Fatty acids $\cdot$ Sea ice $\cdot$ Copepod diets $\cdot$ Life cycles $\cdot$ Acartiidae

\section{INTRODUCTION}

Lipids are accumulated by many polar copepods to provide maintenance energy during periods of low food availability, and to fuel reproductive processes before the onset of the spring phytoplankton bloom (Hagen \& Schnack-Schiel 1996). Of the storage lipids, triacylglycerol is mobilized faster than wax ester and

*E-mail: k.swadling@utas.edu.au tends to be deposited by copepods that do not experience prolonged periods of starvation (Sargent \& Henderson 1986). Substantial quantities of triacylglycerol have been recorded from several species of pelagic Antarctic copepods, including Calanus propinquus (Hagen et al. 1993), Euchirella rostromagna (Hagen et al. 1995) and C. simillimus (Ward et al. 1996), suggesting that feeding by these species is not restricted to the productive summer season. In contrast, Calanoides acutus, which overwinters at depth without feeding (Atkinson et al. 1997), stores large quantities of wax 
esters (Hagen et al. 1993). For those species which remain active during the winter, alternative dietary modes include grazing on heterotrophic protists, microzooplankton and ice-associated flora.

A range of invertebrates, including copepods, feed on ice algae during winter, when the algal standing stock can be considerably higher than in the underlying water column (e.g. Hoshiai 1981). While many species graze at the under-ice surface, a smaller number actually inhabit the interstitial brine system in the ice matrix (Schnack-Schiel et al. 1998, Swadling et al. 2000). Preliminary studies indicate that some icedwelling copepods store lipids in numerous small oil droplets (Dahms et al. 1990), and that at least 1 species, Stephos longipes, stores energy as triacylglycerol (Schnack-Schiel et al. 1995). However, there is little information about changes in lipid stores during the development of ice-associated copepods, and studies of ontogenetic changes in lipid stores of Antarctic copepods are rare (Kattner et al. 1994). Studying these changes will provide insight into how these copepods successfully exploit an unusual marine environment.

We describe the ontogenetic and seasonal changes in the lipid content of marine and lacustrine populations of Paralabidocera antarctica (Acartiidae), a copepod which is abundant in coastal waters of eastern Antarctica. The life cycle of the marine population is coupled strongly to the growth and decay of fast ice, and the associated development of the ice-algal community (Tanimura et al. 1996, Swadling 1998). Briefly, nauplii of $P$. antarctica enter the bottom layers of the sea ice in early autumn, where they overwinter, predominantly as naupliar stages IV and V. In early to mid-spring there is rapid development to copepodite stage III. Beginning in mid-November the population enters a pelagic phase, but remains in close proximity to the ice-water interface. Mating and spawning begin in late December, and it is likely that adults die soon after the end of their reproductive period (Tanimura et al. 1996). Resting eggs are present in the sediment for approximately $4 \mathrm{wk}$ before hatching to the NI stage (Swadling 1998).

The lacustrine population studied was in Ace Lake, 1 of 3 saline lakes of the Vestfold Hills known to contain populations of Paralabidocera antarctica (Bayly 1978, Wright \& Burton 1981, Bayly \& Eslake 1989). These lakes were formed approximately $5000 \mathrm{yr} \mathrm{BP}$, when the retreat of the polar ice cap and isostatic uplift of the land trapped pockets of seawater (Zwartz et al. 1998). The Ace Lake population exhibited several life-cycle characteristics that were different from the coastal population, notably having no association with the lake ice cover during winter (Swadling 1998). Furthermore, the copepodites matured into adults about 1 mo earlier than the coastal population, and most stages were present in the water column throughout the year, albeit sometimes in small proportions. The lacustrine population provided a rare opportunity to extend the examination of the role that lipids play in the life cycle of an ice-dependent copepod by enabling a comparison with a population that has evolved to be largely ice-independent.

The present study investigated whether the gross differences we observed in the life cycles of Paralabidocera antarctica were reflected in the biochemistry, specifically the lipid class and fatty acid composition, of the 2 populations. Specimens of the lacustrine form, collected from Ace Lake during February 1984, were discovered to contain large quantities of triacylglycerol (77\% of total lipids) (Volkman et al. 1988), and from that observation we developed several objectives. Initially we aimed to determine if the coastal population of $P$. antarctica also accumulated triacylglycerol as its primary energy reserve. Once this was confirmed, we examined the lipid class composition of nauplii and copepodites collected from the sea ice and water column. A comparison was made with the Ace Lake population, and the results interpreted in light of the special features of the life cycle of $P$. antarctica, namely its prolonged naupliar development and its association (or lack of) with the seasonal ice cover. Finally, we analysed the fatty acid composition of $P$. antarctica to elucidate possible biochemical pathways of lipid biosynthesis and to provide a basis for comparison with other triacylglycerol-storing Antarctic copepods.

\section{METHODS}

Specimens of Paralabidocera antarctica were collected from a coastal site offshore from Davis Station

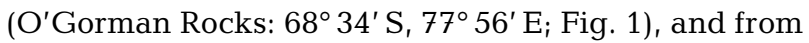
Ace Lake in the Vestfold Hills (68 $\left.{ }^{\circ} 28^{\prime} \mathrm{S}, 78^{\circ} 10^{\prime} \mathrm{E}\right)$. The coastal site had a depth of $23 \mathrm{~m}$, and was covered by ice from March 1994 to January 1995 (maximum thickness: $1.6 \mathrm{~m}$ ). Physical and chemical characteristics of the inshore marine system near Davis Station are detailed in Gibson \& Trull (1999). Ace Lake is stratified, with oxygenated water present to $12 \mathrm{~m}$. The salinity of this water ranges between 6 and 31 (see Rankin et al. 1999 for a review of the chemical and physical characteristics of the lake). Ice cover on the lake persists for at least 11 mo of each year.

The O'Gorman Rocks site was sampled 12 times between 15 December 1993 and 28 December 1994, and Ace Lake 8 times between 22 May 1994 and 13 January 1995. Specimens were collected from the water column with a plankton net (mesh size: $100 \mu \mathrm{m})$ that was towed vertically through $20 \mathrm{~m}$ of the water column at $\mathrm{O}^{\prime}$ Gorman Rocks or through the top $11 \mathrm{~m}$ of 


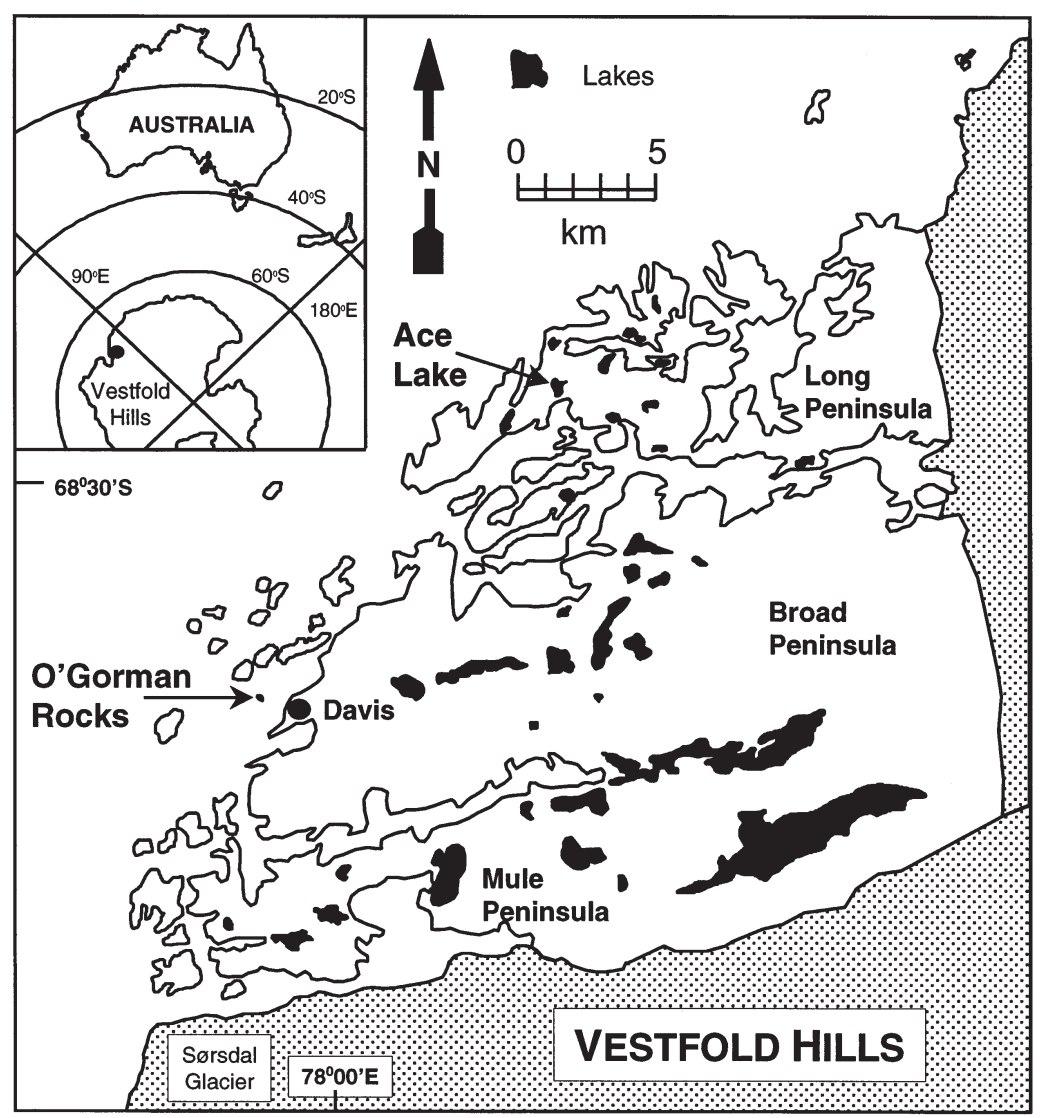

Fig. 1. Sampling locations at O'Gorman Rocks and Ace Lake, Vestfold Hills. Inset shows position of the Vestfold Hills in Antarctica

Additional individuals were collected on each sampling date to determine the water content. The wet mass of 10 to 300 individuals (depending on size) was determined with a Mettler microbalance $( \pm 1 \mu \mathrm{g})$. The specimens were then dried at $60^{\circ} \mathrm{C}$ until constant mass was attained. A wet weight:dry weight relationship was determined for each stage.

Lipids were extracted from samples by a modified 1-phase $\mathrm{CHCl}_{3}-\mathrm{MeOH}$ $\mathrm{H}_{2} \mathrm{O}$ Bligh-Dyer method (White et al. 1979). Determination of the main lipid classes was by thin-layer chromatography-flame ionisation detection (TLCFID) (Volkman et al. 1989, Volkman \& Nichols 1991), with total lipid calculated from the sum of the individual lipid classes.

The fatty acid compositions of 6 copepod samples and 6 samples of particulate matter were analysed after saponification and esterification of an aliquot of the total lipid extract (Volkman et al. 1989). Analyses were performed with a Hewlett Packard 5890 gas chromatograph (GC) (column: $50 \mathrm{~m} \times 0.32 \mathrm{~mm}$ i.d. HP1 cross-linked methyl silicone fused-silica, capillary column) with $\mathrm{H}_{2}$ as the carrier gas. The GC was fitted with a flame-ionisation

Ace Lake. The copepods were transferred to insulated buckets containing cold lake or seawater $\left(-1^{\circ} \mathrm{C}\right)$ and returned alive to the laboratory, where they were sorted. Up to 200 individuals of a given developmental stage were pooled for each analysis, then transferred to pre-extracted $\left(\mathrm{CHCl}_{3} / \mathrm{MeOH}\right) \mathrm{GF} / \mathrm{F}$ filters and frozen at $-70^{\circ} \mathrm{C}$. Sea ice cores were obtained with a SIPRE ice auger (diameter: $76 \mathrm{~mm}$ ), then wrapped in black plastic and returned to the laboratory. The cores were melted into prefiltered (GF/F) seawater in the dark at temperatures of $<4^{\circ} \mathrm{C}$. Copepods were removed from the melted core water with a $53 \mu \mathrm{m}$ sieve, and then processed as above. Naupliar stages I to VI were pooled for lipid analysis and dry weight determinations, as large numbers were required and sorting was time-consuming. Copepodite stages were analysed separately. Between 95 and 200 individuals were pooled for each analysis; therefore, the results represent mean values for each stage and provide no information on individual variation. On several occasions particulate matter was collected from the water column and the sea ice, filtered onto GF/F filters, and frozen at $-70^{\circ} \mathrm{C}$ until analysis. detector set at $310^{\circ} \mathrm{C}$ and a purged split/splitless injector set at $290^{\circ} \mathrm{C}$. Samples were injected using a Hewlett-Packard 7673A autosampler, and the oven temperature was programmed according to the method of Skerratt et al. (1995). Identification of compounds was confirmed by gas chromatography-mass spectrometry, with conditions as described by Phleger et al. (1998), and by comparison of retention time and mass spectral data with data obtained from standards. The fatty acid nomenclature used in this paper designates the total number of carbon atoms: number of double bonds followed by the position of the double bond from the aliphatic end, e.g. 18:1 (n-9). Double bonds were of cis geometry unless otherwise specified.

\section{RESULTS}

\section{Coastal population}

Specimens of Paralabidocera antarctica were collected from the water column and sea ice at the O'Gorman Rocks site for dry weight measurements and lipid 
class analysis. Nauplii and copepodid stages I to IV were isolated from the sea ice cores, while nauplii, CIII, female CV and adult males and females were obtained from the water column. As the differences between copepods sampled from the sea ice and those collected from the water column were small, the data were pooled for presentation of the results. It was not possible on any sampling date to collect sufficient numbers of CV males for analysis. As $P$. antarctica at the coastal site developed rapidly through copepodid stages I to IV, most of these stages were analysed only once.

The dry weight and total lipid content of Paralabidocera antarctica varied considerably between stages (Table 1). Nauplii in both the sea ice and the water column increased in dry weight (DW) from May $(1.5 \mu \mathrm{g})$ to late October $(2.7 \mu \mathrm{g})$. The total amount of lipid present in the nauplii ranged from 0.3 to $1.0 \mu \mathrm{g}$, which accounted for between 16 and 36\% DW. Copepodid stages I to IV increased in weight from 3.2 (CI) to $5.1 \mu \mathrm{g}$ (CIV). The quantity of lipid contained in these stages averaged approximately $33 \%$ DW. Adult males collected in December 1993 averaged $16 \mu \mathrm{g}$ DW and contained $1.6 \mu \mathrm{g}(10 \% \mathrm{DW})$ lipid. A similar result was observed for adult males collected in December 1994. CV females were collected on 1 date only. Their DW was $19.7 \mu \mathrm{g}$, of which $6 \mu \mathrm{g}$ was lipid (30\% DW). Adult females lost substantial weight during both summers, decreasing from 35 to $20 \mu \mathrm{g}$ in DW. Lipid accounted for between 6 and $41 \%$ of the DW of females.
The main lipid classes in Paralabidocera antarctica from O'Gorman Rocks were triacylglycerol and polar lipid, with much smaller quantities of sterol and free fatty acid. Wax esters were not present in these specimens. The lipid stores were distributed throughout the bodies of the copepods in numerous small sacs that were pale yellow to bright orange in colour. The total lipid of the nauplii comprised from 23 to $76 \%$ triacylglycerol, with the remainder mostly polar lipid (Table 1). The copepodid stages contained between 80 and $97 \%$ polar lipid, and 0 to $12 \%$ triacylglycerol. The triacylglycerol content of adult males collected in December 1993 decreased from 30 to $4 \%$ between 2 sampling dates 1 wk apart. In December 1994 the reduction was even greater: From $55 \%$ on 14 December to $2 \%$ on 28 December. The triacylglycerol content of adult females decreased from 65 to $0 \%$ in the 1993 to 1994 summer, and from 69 to $17 \%$ in the 1994 to 1995 summer. CV females contained $20 \%$ triacylglycerol and $75 \%$ polar lipid.

The fatty acid compositions of adult male and female Paralabidocera antarctica collected from the water column on 15 December 1993 are shown in Fig. 2. The major fatty acids (accounting for $72 \%$ ) present in females were 16:1(n-7), 20:5(n-3), 16:0 and 14:0 (in decreasing abundance). The composition of the males was similar, with 16:0, 16:1(n-7), 20:5(n-3), and 14:0 as major components. Compared with the females, male adults contained higher levels of 18:0, 18:1(n-9) and 18:1(n-7). Long-chain monounsaturated fatty acids

Table 1. Paralabidocera antarctica. Dry weight and lipid composition of nauplii, copepodids and adults collected from the sea ice and water column at O'Gorman Rocks. Data for adults are presented for 1993-94 and 1994-95 summers. Mean values for each stage are shown, with the range (minimum-maximum) in parentheses. \% DW: percent dry wt; \% TL: percent total lipid; $\mathrm{n}$ : number of dates on which samples were collected (95 to 200 specimens each)

\begin{tabular}{|c|c|c|c|c|c|c|c|}
\hline Stage & $\begin{array}{l}\text { Collection } \\
\text { period }\end{array}$ & $\begin{array}{l}\text { Dry weight } \\
\left(\mu \text { ind }^{-1}\right)\end{array}$ & $\begin{array}{l}\text { Lipid weight } \\
\left(\mu \mathrm{g} \text { ind } .^{-1}\right)\end{array}$ & $\begin{array}{l}\text { Total lipid } \\
\text { (\% DW) }\end{array}$ & $\begin{array}{c}\text { Triacylglycerol } \\
\text { (\% TL) }\end{array}$ & $\begin{array}{l}\text { Polar lipid } \\
\text { (\% TL) }\end{array}$ & $\mathrm{n}$ \\
\hline NI-NVI & 9 May $94-4$ Nov 94 & $\begin{array}{c}2.1 \\
(1.5-2.7)\end{array}$ & $\begin{array}{c}0.5 \\
(0.3-1.0)\end{array}$ & $\begin{array}{c}23.5 \\
(16.0-36.4)\end{array}$ & $\begin{array}{c}54 \\
(23-76)\end{array}$ & $\begin{array}{c}41 \\
(24-70)\end{array}$ & 9 \\
\hline CI & 21 Oct 94 & 3.2 & 1.0 & 30.1 & 5 & 87 & 1 \\
\hline CII & 21 Oct 94 & 3.4 & 1.3 & 38.2 & 2 & 88 & 1 \\
\hline CIII & 21 Oct $94-7$ Dec 94 & $\begin{array}{c}4.2 \\
(3.9-5.6)\end{array}$ & $\begin{array}{c}1.6 \\
(1.3-1.7)\end{array}$ & $\begin{array}{c}38.0 \\
(30.1-39.0)\end{array}$ & $\begin{array}{c}9 \\
(5-12)\end{array}$ & $\begin{array}{c}86 \\
(80-89)\end{array}$ & 3 \\
\hline CIV & 21 Oct 94 & 5.1 & 1.4 & 27.4 & 0 & 97 & 1 \\
\hline CV female & 28 Dec 94 & 19.7 & 6.0 & 30.4 & 20 & 75 & 1 \\
\hline 1993-94 summer & & & & & & & \\
\hline CVI male & 15 Dec 93-22 Dec 93 & $\begin{array}{c}16.1 \\
(15.9-16.3)\end{array}$ & $\begin{array}{c}1.6 \\
(1.5-1.8)\end{array}$ & $\begin{array}{c}10.1 \\
(9.2-11.0)\end{array}$ & $\begin{array}{c}17 \\
(4-30)\end{array}$ & $\begin{array}{c}80 \\
(70-91)\end{array}$ & 2 \\
\hline CVI female & 15 Dec 93-19 Jan 94 & $\begin{array}{c}28.8 \\
(19.6-35.8)\end{array}$ & $\begin{array}{c}5.0 \\
(1.2-12.5)\end{array}$ & $\begin{array}{c}16.1 \\
(6.0-40.9)\end{array}$ & $\begin{array}{c}33 \\
(0-65)\end{array}$ & $\begin{array}{c}62 \\
(29-100)\end{array}$ & 5 \\
\hline 1994-95 summer & & & & & & & \\
\hline CVI male & 14 Dec $94-28$ Dec 94 & $\begin{array}{c}16.7 \\
(12.6-20.1)\end{array}$ & $\begin{array}{c}1.5 \\
(1.1-2.4)\end{array}$ & $\begin{array}{c}8.8 \\
(6.0-11.9)\end{array}$ & $\begin{array}{c}25 \\
(2-55)\end{array}$ & $\begin{array}{c}74 \\
(49-96)\end{array}$ & 5 \\
\hline CVI female & 14 Dec $94-28$ Dec 94 & $\begin{array}{c}29.7 \\
(22.0-34.9)\end{array}$ & $\begin{array}{c}5.9 \\
(2.5-10.0)\end{array}$ & $\begin{array}{c}20.3 \\
(8.9-38.7)\end{array}$ & $\begin{array}{c}55 \\
(17-69)\end{array}$ & $\begin{array}{c}39 \\
(24-77)\end{array}$ & 5 \\
\hline
\end{tabular}




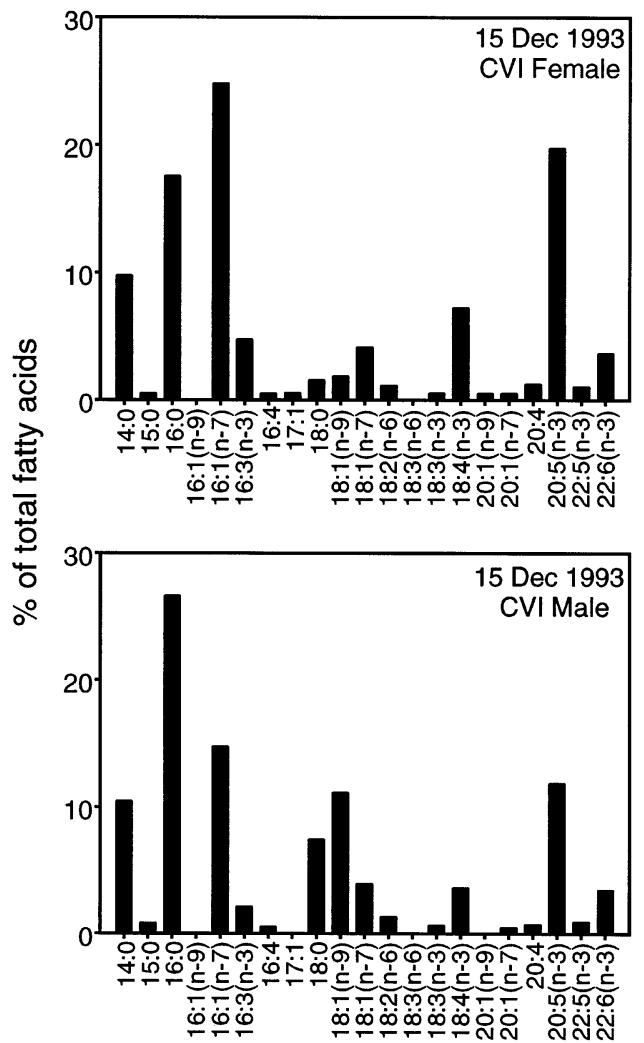

Fig. 2. Paralabidocera antarctica. Composition of major fatty acids (weight \%) of adult females and males collected from O'Gorman Rocks on 15 December 1993 [20:1(n-7), 20:1(n-9)] accounted for $<1 \%$ of the total in both of the sexes. 18:4(n-3) represented 7 and $4 \%$ of the total fatty acids in females and males respectively.

\section{Lacustrine population}

Nauplii and copepodites of Paralabidocera antarctica were collected from the water column of Ace Lake for dry weight measurements and lipid content, and class analysis. Sufficient specimens were available for each stage to be analysed on at least 2 dates. Lake ice cores were collected regularly; however, copepods were not recorded in the cores. As for the coastal population, there was substantial variation in the DW and lipid content of the different stages (Table 2). The DW of the nauplii increased from $1.5 \mu \mathrm{g}$ in May to $2.6 \mu \mathrm{g}$ in November, before decreasing slightly to $2.3 \mu \mathrm{g}$ in December. Nauplii contained between 0.5 and $0.9 \mu \mathrm{g}$ lipid (20 to $43 \%$ DW). Dry weights of the copepodids increased from $2.7 \mu \mathrm{g}$ at the CI stage to $4.7 \mathrm{mg}$ at CIV. These copepodid stages generally contained less lipid than the nauplii, averaging $0.6,0.3,0.3$ and $0.6 \mu \mathrm{g}$ in CI, CII, CIII and CIV respectively $(20,12,7$ and $14 \%$ DW). Males almost doubled in DW from the CV (5.7 $\mathrm{mg})$ to the CVI (9.5 $\mathrm{\mu g})$ stage. Both the CV and the CVI males showed a decrease in their lipid stores with time. Adult males averaged $1.5 \mathrm{mg}$ lipid (20\% DW) until 13 January 1995, when their lipid content had dropped

Table 2. Paralabidocera antarctica. Dry weight and lipid composition of nauplii, copepodids and adults collected from the water column at Ace Lake. Mean values for each stage are shown, with the range (minimum-maximum) in parentheses. \% DW: percent dry wt; \% TL: percent of total lipid; $\mathrm{n}$ : number of dates on which samples were collected (110 to $200 \mathrm{specimens}$ each)

\begin{tabular}{|c|c|c|c|c|c|c|c|}
\hline Stage & $\begin{array}{l}\text { Collection } \\
\text { period }\end{array}$ & $\begin{array}{l}\text { Dry weight } \\
\text { ( } \mu \text { g ind } .^{-1} \text { ) }\end{array}$ & $\begin{array}{l}\text { Lipid weight } \\
\left(\mu \mathrm{g} \text { ind } .^{-1}\right)\end{array}$ & $\begin{array}{l}\text { Total lipid } \\
\text { (\% DW) }\end{array}$ & $\begin{array}{c}\text { Triacylglycerol } \\
\text { (\% TL) }\end{array}$ & $\begin{array}{l}\text { Polar lipid } \\
\text { (\% TL) }\end{array}$ & $\mathrm{n}$ \\
\hline NI-NVI & 22 Mar 94-23 Dec 94 & $\begin{array}{c}2.2 \\
(1.5-2.6)\end{array}$ & $\begin{array}{c}0.7 \\
(0.5-0.9)\end{array}$ & $\begin{array}{c}32.1 \\
(19.6-42.8)\end{array}$ & $\begin{array}{c}75 \\
(59-85)\end{array}$ & $\begin{array}{c}22 \\
(15-41)\end{array}$ & 7 \\
\hline $\mathrm{CI}$ & 22 Jul 94-23 Nov 94 & $\begin{array}{c}2.7 \\
(2.5-2.9)\end{array}$ & $\begin{array}{c}0.6 \\
(0.3-0.9)\end{array}$ & $\begin{array}{c}19.9 \\
(12.1-31.0)\end{array}$ & $\begin{array}{c}63 \\
(53-69)\end{array}$ & $\begin{array}{c}31 \\
(20-47)\end{array}$ & 6 \\
\hline CII & 21 Sep $94-12$ Oct 94 & $\begin{array}{c}3.0 \\
(2.9-3.2)\end{array}$ & $\begin{array}{c}0.3 \\
(0.3-0.4)\end{array}$ & $\begin{array}{c}11.6 \\
(10.3-13.0)\end{array}$ & $\begin{array}{c}18 \\
(16-20)\end{array}$ & $\begin{array}{c}73 \\
(70-76)\end{array}$ & 2 \\
\hline CIII & 23 Nov $94-23$ Dec 94 & $\begin{array}{c}3.8 \\
(3.8-3.9)\end{array}$ & $\begin{array}{c}0.3 \\
(0.2-0.4)\end{array}$ & $\begin{array}{c}6.7 \\
(4.3-9.2)\end{array}$ & $\begin{array}{c}25 \\
(22-27)\end{array}$ & $\begin{array}{c}76 \\
(75-77)\end{array}$ & 2 \\
\hline CIV & 12 Oct $94-23$ Dec 94 & $\begin{array}{c}4.7 \\
(4.5-4.8)\end{array}$ & $\begin{array}{c}0.6 \\
(0.6-0.8)\end{array}$ & $\begin{array}{c}13.8 \\
(12.4-16.8)\end{array}$ & $\begin{array}{c}22 \\
(17-27)\end{array}$ & $\begin{array}{c}73 \\
(64-83)\end{array}$ & 4 \\
\hline CV male & 10 Nov $94-23$ Nov 94 & $\begin{array}{c}5.7 \\
(5.4-5.9)\end{array}$ & $\begin{array}{c}1.5 \\
(0.9-2.1)\end{array}$ & $\begin{array}{c}25.9 \\
(16.1-35.6)\end{array}$ & $\begin{array}{c}43 \\
(42-44)\end{array}$ & $\begin{array}{c}51 \\
(46-56)\end{array}$ & 2 \\
\hline CV female & 10 Nov $94-23$ Dec 94 & $\begin{array}{c}6.3 \\
(6.0-6.7)\end{array}$ & $\begin{array}{c}1.4 \\
(1.0-2.2)\end{array}$ & $\begin{array}{c}22.3 \\
(16.6-32.8)\end{array}$ & $\begin{array}{c}28 \\
(25-32)\end{array}$ & $\begin{array}{c}67 \\
(62-69)\end{array}$ & 3 \\
\hline CVI male & 10 Nov $94-23$ Dec 94 & $\begin{array}{c}9.5 \\
(8.8-10.4)\end{array}$ & $\begin{array}{c}1.5 \\
(0.5-2.2)\end{array}$ & $\begin{array}{c}16.0 \\
(5.3-21.0)\end{array}$ & $\begin{array}{c}19 \\
(0-39)\end{array}$ & $\begin{array}{c}71 \\
(44-90)\end{array}$ & 4 \\
\hline CVI female & 10 Nov 94-13 Jan 95 & $\begin{array}{c}13.0 \\
(11.0-14.2)\end{array}$ & $\begin{array}{c}4.1 \\
(0.5-5.8)\end{array}$ & $\begin{array}{c}30.6 \\
(4.9-45.1)\end{array}$ & $\begin{array}{c}35 \\
(0-56)\end{array}$ & $\begin{array}{c}61 \\
(35-97)\end{array}$ & 5 \\
\hline
\end{tabular}


to $0.5 \mu \mathrm{g}(5 \% \mathrm{DW})$. Females also doubled in DW from the CV $(6.3 \mu \mathrm{g})$ to the CVI stage $(13 \mu \mathrm{g})$. Female CV contained approximately $1.4 \mu \mathrm{g}$ of lipid (22\% DW), and adult females collected in November and December of 1994 contained between 3 and $6 \mu \mathrm{g}$ of lipid ( 25 to $44 \%$ DW). The females collected on 13 January 1995 contained only $0.5 \mu \mathrm{g}$ of lipid ( $5 \% \mathrm{DW}$ ).

The lipids of the lacustrine population of Paralabidocera antarctica comprised mainly triacylglycerol and polar lipid, with smaller quantities of sterol and free fatty acid. Traces of wax ester $(<0.1 \%)$ were recorded on 3 occasions. The naupliar and CI stages stored abundant triacylglycerol, averaging 75 and $63 \%$ of the total lipid respectively (Table 2). This proportion decreased to about $20 \%$ in the CII to CIV stages. Stage $\mathrm{CV}$ males and adult males collected in November contained approximately $40 \%$ triacylglycerol. However, the amount present in adult males decreased to zero in late December and early January. The triacylglycerol content of CV females was about $28 \%$, and increased to approximately $50 \%$ in adult females collected in November. There was a decrease in the proportion of triacylglycerol present in adult females in mid-December $(19 \%)$, then a rise in late December $(56 \%)$. In mid-
January the females did not contain any triacylglycerol and their total lipid was very low.

Fatty acid analysis was performed on 4 samples from the Ace Lake population (Fig. 3). The major components present were 16:0, 16:1(n-7), 18:1(n-9), 18:3(n-3), 18:4(n-3), 20:5(n-3) and 22:6(n-3). These 7 compounds accounted for between 77 and $81 \%$ of all fatty acids present. The nauplii differed from the $\mathrm{CV}$ males and CVI females in that 18:3(n-3) and 18:4(n-3) were found in higher proportions than 20:5(n-3) and 22:6(n-3). Females collected in January 1995 contained considerably less 18:3(n-3) and no 18:4(n-3) compared to those collected in December 1994.

\section{Particulate matter}

The lipid class composition of particulate matter collected from the 2 sites is shown in Table 3 . At the coastal site, particulate matter was collected from $2 \mathrm{~m}$ depth in the water column and from the sea ice. Polar lipid, including phospholipid and glycolipid, was the most abundant class in both samples. Of the non-polar lipid classes, triacylglycerol, free fatty acid and sterol
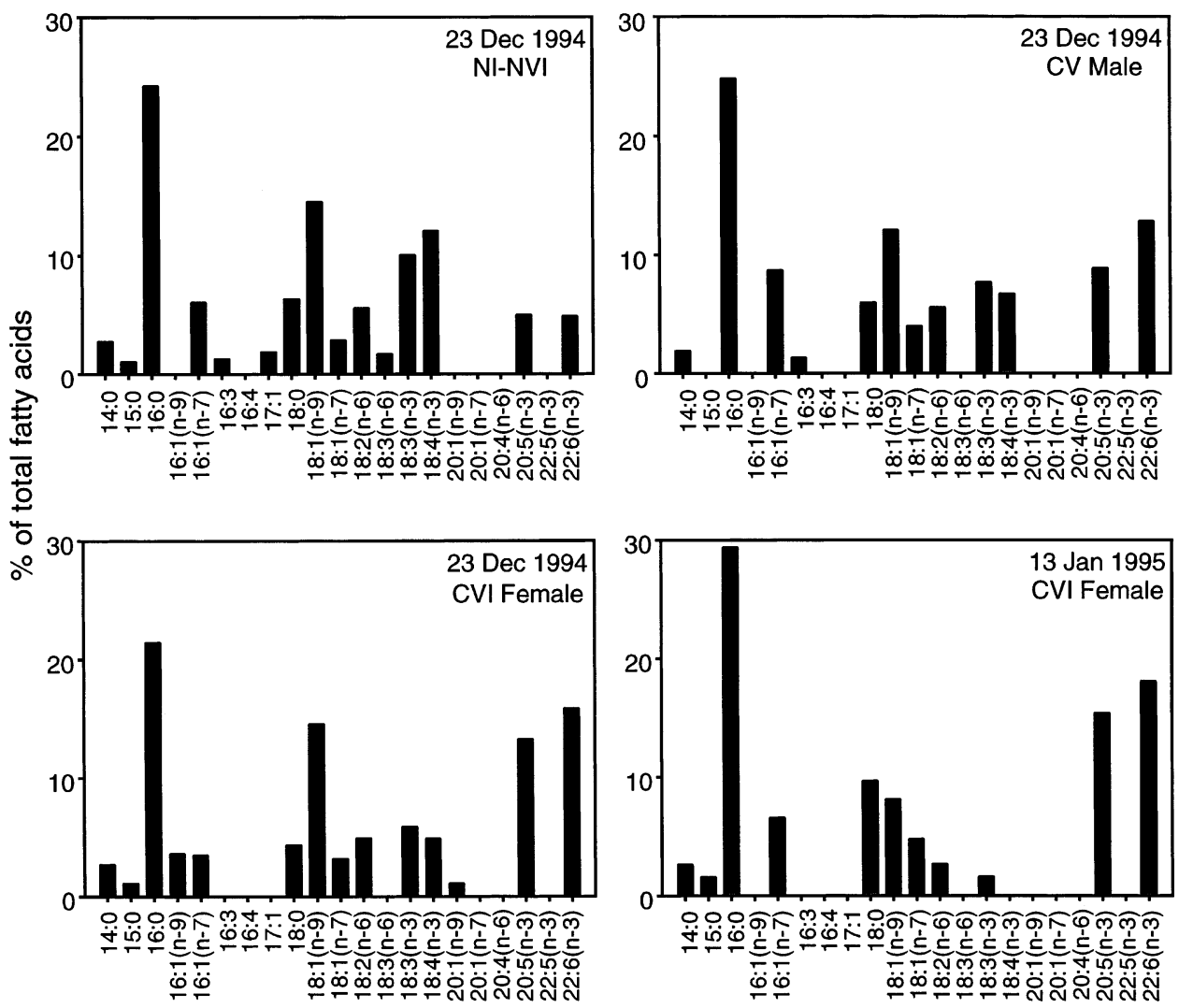

Fig. 3. Paralabidocera antarctica. Composition of major fatty acids (weight\%) of nauplii, CV males and adult females collected from Ace Lake on 23 December 1994 and 13 January 1995 
Table 3. Lipid class composition of particulate matter collected from the water column in Ace Lake, and from the water column and sea ice at $\mathrm{O}^{\prime}$ Gorman Rocks. Polar lipids are those which remained at the origin and include phospholipids and glycolipids. \% TL: percent of total lipid; HC/WE: hydrocarbon and wax ester that co-eluted; tr: trace $(<1 \%)$; -: not detected

\begin{tabular}{|c|c|c|c|c|c|c|}
\hline \multirow{2}{*}{ Lipid } & \multicolumn{2}{|c|}{ _- O'Gorman Rocks _- } & \multirow[b]{2}{*}{$\begin{array}{c}22 \text { May } 94 \\
(2 \mathrm{~m})\end{array}$} & \multicolumn{2}{|c|}{ Ace Lake } & \multirow[b]{2}{*}{$\begin{array}{c}23 \text { Dec } 94 \\
(2 \mathrm{~m})\end{array}$} \\
\hline & $\begin{array}{c}6 \text { Jan } 94 \\
(2 \mathrm{~m})\end{array}$ & $\begin{array}{c}9 \text { Aug } 94 \\
\text { (sea ice) }\end{array}$ & & $\begin{array}{c}23 \text { Nov } 94 \\
(2 \mathrm{~m})\end{array}$ & $\begin{array}{c}10 \text { Dec } 94 \\
(2 \mathrm{~m})\end{array}$ & \\
\hline Total polar lipid $\left(\mu \mathrm{g}^{-1}\right)$ & 44 & 1 & 51 & 52 & 48 & 84 \\
\hline Total non-polar lipid $\left(\mu \mathrm{g} \mathrm{l}^{-1}\right)$ & 28 & 0.5 & 156 & 61 & 35 & 145 \\
\hline HC/WE (\% TL) & - & - & $\operatorname{tr}$ & 3 & 1 & 1 \\
\hline Triacylglycerol (\% TL) & 11 & 28 & 74 & 1 & 6 & 7 \\
\hline Free fatty acid (\% TL) & 16 & 2 & 1 & 41 & 36 & 55 \\
\hline Sterol (\% TL) & 12 & - & $\operatorname{tr}$ & 1 & - & $\operatorname{tr}$ \\
\hline
\end{tabular}

were the most common. In the water column, 5 components accounted for $65 \%$ of the total fatty acids: 16:0, 18:0, 18:1(n-9), 14:0 and 16:1(n-7) (in decreasing abundance) (Fig. 4). In the sea ice, 16:0 and 16:1(n-7) accounted for $44 \%$ of the total, and 18:0, 18:1(n-9) and 18:1 (n-7) for a further $36 \%$ (Fig. 4). Polyunsaturated fatty acids (PUFA) comprised 9 and $21 \%$ in the sea-ice and water-column samples, respectively.

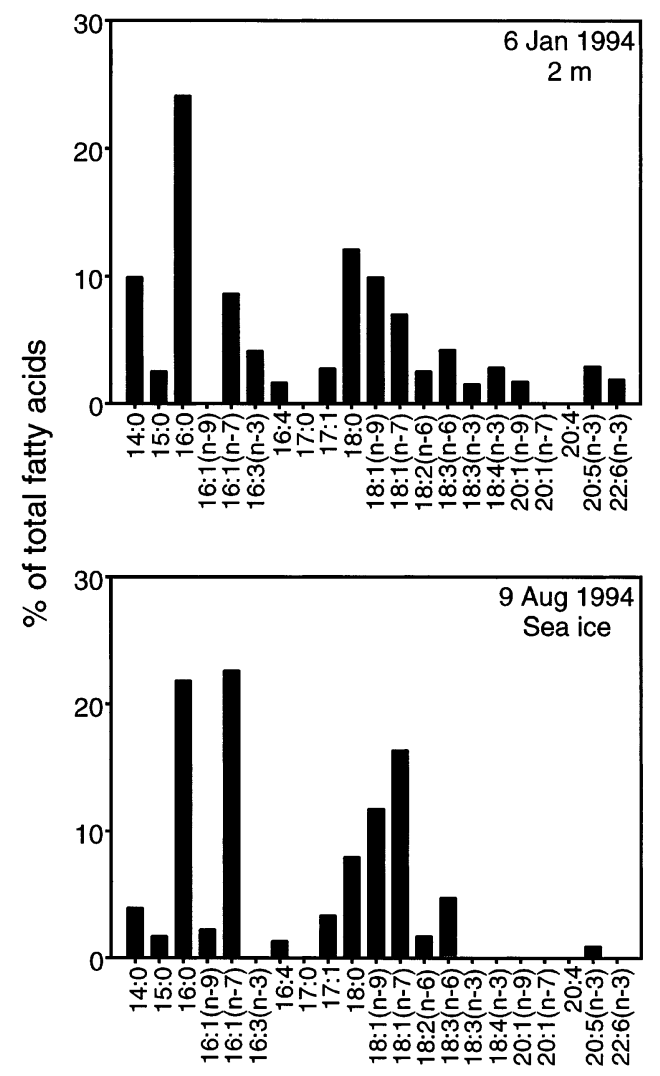

Fig. 4. Particulate matter. Fatty acid composition (weight\%) of particulate matter at $2 \mathrm{~m}$ depth in the water column and the sea ice at O'Gorman Rocks
Particulate matter was collected from Ace Lake at $2 \mathrm{~m}$ water depth on 4 occasions. Except on 1 occasion, non-polar lipids were more abundant than polar lipids (Table 3). Triacylglycerol and free fatty acid were the most common classes recorded. The commonest fatty acids present were 16:0 and 18:1(n-9), accounting for between 46 and $55 \%$ of the total (Fig. 5). Other abundant components included 16:1(n-7) 18:4(n-3) and 18:2(n-6) (which sometimes co-eluted with 18:3(n-3)). PUFA levels ranged between 38\% (May) and 17\% (November).

\section{DISCUSSION}

\section{Coastal population}

The patterns of lipid storage and changes in dry weight reflected the life cycle of Paralabidocera antarctica. Nauplii appeared in the water column in late January, and colonised the sea ice when it formed in early March. The copepods then developed rapidly to naupliar stages IV (the first stage that feeds; Hoshiai et al. 1987) and V, which were the principal overwintering stages (Swadling 1998). P. antarctica is unusual in having a protracted naupliar stage. These young stages of copepods are generally assumed to have less energy-storing capacity and to be less able to cope with extremes in the environment (Marshall \& Orr 1955). The present study showed, however, that nauplii of $P$. antarctica had substantial energy reserves in the form of triacylglycerol (up to $76 \%$ of total lipid). Three explanations could account for this observation: (1) Nauplii might deposit a portion of their energy intake as lipid stores that can be mobilized when prey become scarce; nauplii and algae have a heterogeneous distribution in sea ice (Swadling et al. 1997, 2000), and the large quantities of triacylglycerol in the nauplii might indicate that they experienced shortterm periods of starvation between successful foraging 

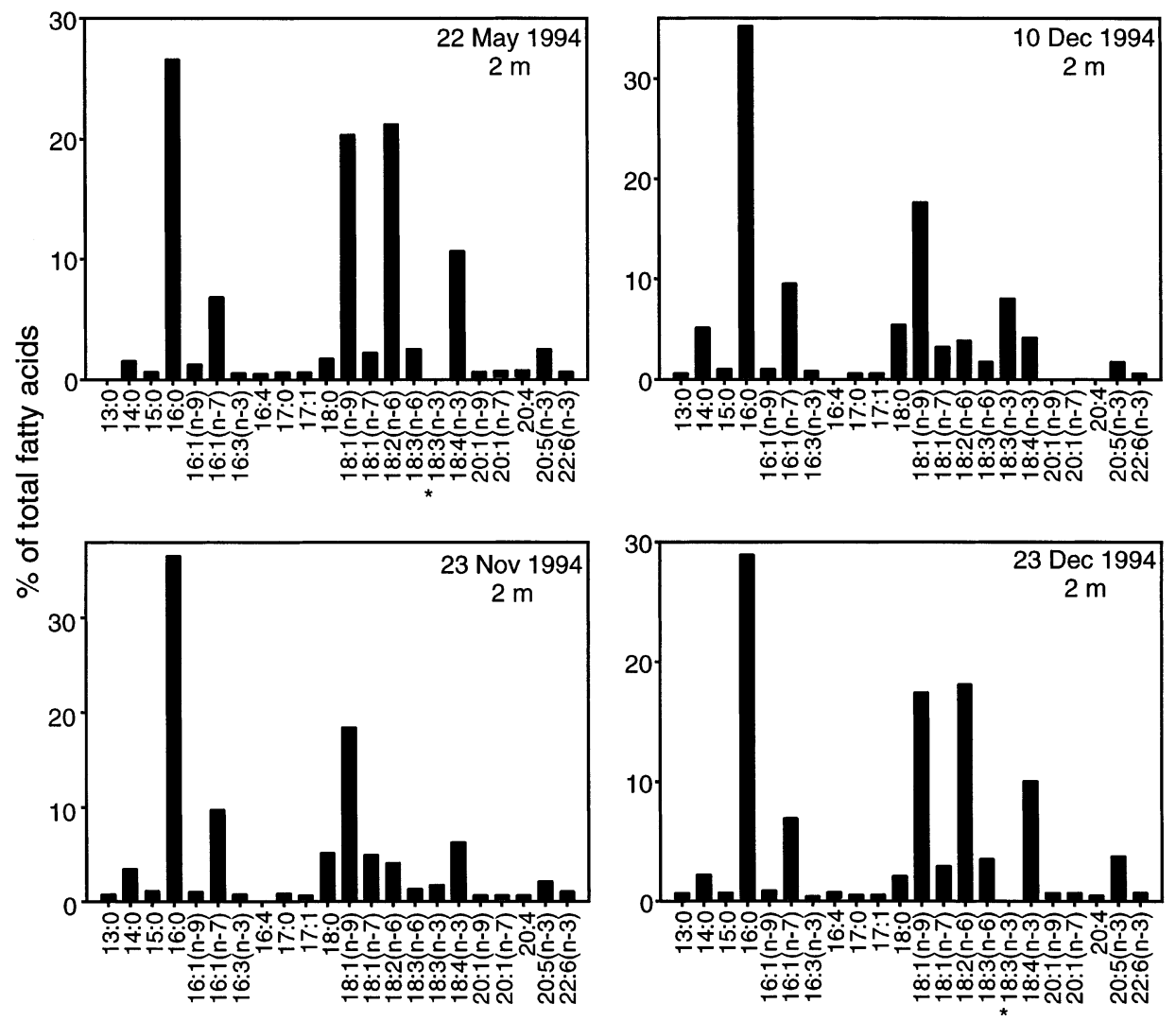

Fig. 5. Particulate matter. Fatty acid composition (weight\%) of particulate matter collected from $2 \mathrm{~m}$ water depth in Ace Lake on 4 occasions. ${ }^{*}$ This compound co-eluted with 18:2(n-6)

bouts. (2) Prey might be consistently available and the lipid stores of nauplii may simply reflect the lipid-rich nature of their diet; ice algae can be lipid-rich, depending on environmental and other factors (Nichols et al. 1988, 1989, Palmisano et al. 1988), and profiles of ice algae at our study site showed high, although variable, concentrations of lipid. (3) It is possible that triacylglycerol synthesis from other compound classes, such as carbohydrates, may have occurred. We believe the second pathway to be most likely, although further research is required to ascertain the relative importance of each.

Development of the coastal population from stages NVI to CIV occurred between early October and early November, and, as the population matured, it shifted habitat from the sea ice to the water column. Stages CI to CIV did not store large quantities of triacylglycerol, implying that their energy intake was diverted primarily to somatic growth. Further, the proportion of polar lipid, which is associated mainly with structural components such as cell membranes, was very high in these stages. During this phase of the copepodids' development, ice algae formed a thick, brown mat on the bottom 2 to $3 \mathrm{~cm}$ of ice at the sampling site, and it seems likely that the copepodids were able to forage consistently. The investment of metabolic energy intake into rapid development coincided with the peak in ice algal biomass (Swadling 1998), and probably ensured that Paralabidocera antarctica reached maturity before the sea ice broke out. In contrast, large, pelagic Antarctic species invest metabolic energy into somatic growth of their copepodids in order to reach a stage that is capable of overwintering (Kattner et al. 1994). The lack of accumulation of triacylglycerol by young copepodids of $P$. antarctica suggests either that they did not have to endure long periods of starvation, or that the ice algae were lipid-poor during that phase of the copepods' development. Ice algae sampled during this period contained high concentrations of lipid (up to $1150 \mathrm{mg} \mathrm{m}^{-2}$; Swadling 1998), suggesting that the second explanation is not the main factor affecting lipid storage by $P$. antarctica.

The dry weight of Paralabidocera antarctica did not increase markedly as it matured, which is different to the exponential growth patterns of dominant, pelagic species (Kattner et al. 1994). Our observations support the hypothesis of Tanimura et al. (1996) that the dimensions of the brine channel system in sea ice might provide a physical constraint to copepod growth. 
Development from stage CIV to adults took between 3 and $4 \mathrm{wk}$, and it was during this phase of growth that the largest increases in dry weight occurred. Adults were abundant in the water column for a short period only, which coincided with a phytoplankton bloom in surface waters (Gibson et al. 1997a). There was a dramatic reduction in triacylglycerol content of both sexes over a short (approximately $2 \mathrm{wk}$ ) period that, as far as we are aware, has not been reported for other polar copepods. Food availability and other environmental conditions were highly favourable at the time of their appearance, so adults must primarily utilize their lipid stores to fuel reproduction (e.g. Hagen \& SchnackSchiel 1996). Triacylglycerol was accumulated by females to fuel oogenesis, copulation and spawning, whereas males probably utilized their lipid stores for spermatogenesis, copulation and attachment of the spermatophore. Reproduction by Paralabidocera antarctica was completed in a brief period before sea ice break-out, so mobilization of lipid stores along with continual grazing ensured that the maximum number of eggs was laid in as short a time as possible. The transfer of lipid from the females to the eggs is an investment in sustaining the growth and development of the NI to NIII stages, which do not feed (Hoshiai et al. 1987). The marked decline in the lipid content of adults is further evidence for the hypothesis of Tanimura et al. (1996) that they die soon after spawning. A similar strategy has been suggested for adult male Euphausia superba (Virtue et al. 1996), based on the finding of negligible amounts of triacylglycerol in this stage.

\section{Lacustrine population}

Paralabidocera antarctica was distributed throughout the top $12 \mathrm{~m}$ of the water column of Ace Lake, and was not recorded in the ice cores (Swadling 1998). Individuals in this population were smaller than those in the coastal population; this became more evident in the older stages. The large difference in dry weight was unsurprising, as the length of adults in Ace Lake was found to be approximately $40 \%$ that of the marine population (Bayly 1978). The warmer temperatures, and/or the lower availability of food, experienced by the lacustrine population might explain this difference in adult size.

In general, nauplii and copepodid stages I to IV of the lacustrine population contained more triacylglycerol than the coastal population, which might indicate that successful foraging bouts by the copepods were more sporadic in the lake, or that the available diet was lipid-rich. Mean triacylglycerol levels in particulate matter at $2 \mathrm{~m}$ in the water column in Ace Lake were high from April to August 1994 (29\%; range $=5$ to
$76 \%$ ) and lower from September 1994 to January 1995 $(6 \%$; range $=0$ to $27 \%)$ (Swadling 1998). Ace Lake is an oligotrophic lake with low chlorophyll a concentrations in the oxygenated surface waters $(0.5$ to $3.3 \mu \mathrm{g}$ $\mathrm{l}^{-1}$ ) and in the ice cover (0.3 to $1.0 \mu \mathrm{g} \mathrm{l}^{-1}$ ) (Swadling 1998). Alternative food sources include the benthic algal mats which fringe the lake; however, nothing is known about the contribution of this material to the diet of Paralabidocera antarctica. The 4 dominant protists present in the oxic zone of the water columnPyramimonas gelidicola, Mesodinium rubrum, an unidentified microflagellate possibly belonging to the family Prymnesiophyceae, and an unidentified cryptomonad - have a vertically stratified distribution as a response to gradients in light levels and nutrient concentrations (Burch 1988, Bell \& Laybourn-Parry 1999). An unarmoured dinoflagellate has also been recorded, although in low abundances (Burch 1988). The copepodites of $P$. antarctica were also stratified, with CIII, CIV and adults preferring the under-ice environment, and CV congregating deeper in the water column, in a study undertaken during the summer of 1982 (Bayly \& Burton 1987). Vertical stratification of the copepods was not examined in the present study. However, if such partitioning is a regular phenomenon in this population, it suggests a division of the food supply and might be a means of avoiding intra-specific competition for resources.

The proportion of triacylglycerol increased as the population developed to CV, with lipid probably accumulated to fuel gonadogenesis in the CVI stage. Adults were present in Ace Lake (43 d) for longer than at the coastal site (20 d) (Swadling 1998), and thus the reproductive period was potentially longer. Lipid stores in the males showed a similar trend to those in the coastal population, with triacylglycerol being depleted over time and the overall lipid content decreasing substantially. Females, however, exhibited 2 peaks in their triacylglycerol content. Examination of the ovaries showed contemporaneous peaks in the proportion of gravid females in the population (K.M.S. unpubl. data). These observations are consistent with the notion that a majority of the population takes advantage of the early spring increase in phytoplankton and reproduces in November, while a smaller portion reproduces in late December. Whether these latter individuals have a delayed development as a result of environmental cues or other factors is uncertain.

\section{Fatty acids}

The fatty acids of Paralabidocera antarctica were composed primarily of short-chain $(<22)$ components, suggesting that this species has a biosynthetic path- 
way similar to that of Euchirella rostromagna (Hagen et al. 1995) and Calanus simillimus (Ward et al. 1996), for which the end products of lipogenesis in E. rostromagna are 16:0, 18:1(n-9) and its isomer 18:1(n-7) (Hagen et al. 1995). This pathway is quite different to that of C. propinquus (Hagen et al. 1993), which synthesises triacylglycerol via elongation of $18: 1(\mathrm{n}-9)$ to 20:1(n-9), and then to the 22:1(n-9) fatty acid. This unusual biochemical pathway is thought to be very energy-efficient (Hagen et al. 1993). Evidence suggests that all these species store triacylglycerol and feed during winter, ingesting ice algae, metazoans or a combination of the 2 (Hoshiai et al. 1987, Hopkins et al. 1993, Ward et al. 1996). However, it is unlikely that this dietary intake is sufficient to meet all their daily calorific needs, and triacylglycerol provides a shortterm energy reserve that can be mobilised quickly. The fatty acid profile of $P$. antarctica was similar to that of E. rostromagna; thus, it is proposed that the biochemical pathways of the 2 species are similar.

\section{Coastal population}

Information on the diet of Paralabidocera antarctica was elucidated from the fatty acid profiles determined for each population, although direct comparison was difficult due to the different methods of sampling the copepods (using an integrated net tow) and the particulate matter (which was collected with a discrete water-sampling bottle). Nevertheless, examination of the fatty acid profiles of the particulate matter and $P$. antarctica enabled a preliminary investigation into the diet of this species. 16:1(n-7) was present in high proportions in adult males $(15 \%)$ and females $(25 \%)$ of the coastal population, providing biochemical support for the observation that adult $P$. antarctica feed on diatoms at the ice-water interface (Hoshiai et al. 1987). In diatoms the ratio of 16:1 to 16:0 is usually $>1$ (Skerratt et al. 1995), and tends to be higher in herbivorous copepods than in omnivorous species (Ward et al. 1996). The ratio of these fatty acids in females at the coastal site (1.4) was higher than that of males (0.6). Together with the high proportions of 20:5(n-3) and 14:0, these findings indicate that diatoms were the dominant component of the diet of the females but were less important for the males.

18:4(n-3), a biomarker for cryptomonads when considered in combination with other profile features of the fatty acids (Volkman et al. 1989, Skerratt et al. 1995; and see below for the lacustrine population), was also detected in the coastal copepods (females $7 \%$, males $4 \%$ ). Cryptomonads were present at $2 \mathrm{~m}$ in the water column in December 1993 (Gibson et al. 1997a), and were possibly ingested by the copepods. Colonies of Phaeocystis antarctica were common in the water column during the same period (Gibson et al. 1997a). This species contains low levels of 18:4(n-3) (cf. $P$. pouchetii), and this fatty acid cannot be considered a biomarker (Nichols et al. 1991). Based on the fatty acid profiles in Nichols et al. (1991), we cannot conclude that $P$. antarctica (originally analysed as $P$. pouchetii but later re-classified; Medlin et al. 1994) made a significant contribution to the diet of the copepod Paralabidocera antarctica.

\section{Lacustrine population}

In Ace Lake, diatoms are a small component of the phytoplankton assemblage (Burch 1988, Bell \& Laybourn-Parry 1999), consistent with the observation that 16:1(n-7) was a minor component ( 3 to $9 \%$ ) of the fatty acid profile of the lacustrine population. The 16:1/16:0 ratio was always much less than 1 (0.22 to 0.35$)$, indicating that other, non-diatom species were more important in the diet of lacustrine Paralabidocera antarctica. In all the lake individuals, levels of 22:6(n-3) were either similar to (nauplii) or greater than 20:5(n-3). This feature is in contrast to the diatom-feeding coastal populations, and supports the trend observed from the 16:1/16:0 ratios. Species which contain elevated 20:5(n-3) and 22:6(n-3) were the main dietary components of the lake population.

Common phytoplankton species present in Ace Lake include Pyramimonas gelidicola, an unidentified cryptomonad, and an unidentified prymnesiophyte (Burch 1988, Bell \& Laybourn-Parry 1999), and these species could contribute to the copepods' diet. $P$. gelidicola is high in 16:4 and 18:3, with less 18:4 fatty acids, while cryptomonads are high in 18:4 and 18:3, with less 16:4 (Volkman et al. 1989, Skerratt et al. 1995, P. Mansour et al. unpubl. data). We note that there was no 16:4 present in the copepods, suggesting (based on the fatty acid profiles alone) that they were not grazing on $P$. gelidicola. However, 16:4 might not be a useful biomarker, because although diatoms are often rich in this fatty acid, it is not always found in high proportions in copepods that feed on diatoms (e.g. Calanus glacialis; Hirche \& Kattner 1993). As P. gelidicola was most common at $10 \mathrm{~m}$ (Swadling 1998), it is possible that it contributed to the diets of adult males, which can be quite abundant at 10 m (Bayly \& Burton 1987), but no fatty acid profiles were determined for this stage.

18:4(n-3) was abundant in the $2 \mathrm{~m}$ particulate sample collected on 23 December 1994 and also in the diets of nauplii, CV males and females (5 to $12 \%$ ) collected on the same date. As noted above, cryptomonads contain elevated levels of 18:4(n-3) with, in addition, high levels of 18:3, a very low 16:1/16:0 ratio (near 0.2 ), and 
20:5 and 22:6 at lower levels (with 20:5 >22:6) than the main $\mathrm{C}_{18}$ PUFA. As these collective features were also observed in the fatty acid profiles of Paralabidocera antarctica, it appears that the copepod grazes on the unidentified cryptomonad in Ace Lake. During the present study, the highest abundance of the cryptomonad was recorded at $2 \mathrm{~m}$ in late November (Gibson et al. 1997b), when adult females became abundant in the water column (Swadling 1998). The unidentified prymnesiophyte was likewise common at $2 \mathrm{~m}$ (J.A.E.G. unpubl. data), and as this organism may also contain high levels of 18:4 it could form part of the diet of $P$. antarctica. In Ace Lake the nauplii had a different fatty acid profile from the older stages, with 22:6(n-3) and 20:5(n-3) at lower levels in the nauplii. It appears that de novo fatty acid synthesis was less pronounced in the nauplii than in the older stages, a finding similar to that of Kattner et al. (1994) for young copepodids of large pelagic species. Alternatively, dietary differences between the stages could account for these differences.

An earlier study (Volkman et al. 1988) of the lipids of a limited number of samples of Paralabidocera antarctica from Ace Lake showed similar trends in lipid class composition to our results. Whilst fatty acid profiles were obtained for selected particulate matter samples in the earlier study, profiles for the copepods were not determined. Through the comparison of marine and lacustrine individuals and the seasonal sampling at both sites, our study builds significantly on the earlier findings and also demonstrates the complementary nature of lipid class and fatty acid profiling in providing information on both the copepods' nutritional status and their dietary preferences.

\section{CONCLUSION}

Triacylglycerol was the main storage lipid of both the lacustrine and coastal populations of Paralabidocera antarctica, supporting the original finding of Volkman et al. (1988). Trace levels of wax ester were only present in some lacustrine individuals. Nauplii at both sites accumulated triacylglycerol, possibly as a response to an irregular food supply and/or from ingesting a lipid-rich diet. Copepodids at the coastal site developed during a time when the ice algal biomass was very high, and they did not lay down energy reserves. In contrast, copepodids in Ace Lake were subjected to a patchy food environment and maintained some energy stores. Adults of both populations seemed to utilize their lipid deposits primarily for fueling reproduction, a strategy in common with large, pelagic species (Hagen \& Schnack-Schiel 1996). While it appears that isolation from the marine environment has influenced the life cycle of $P$. antarctica, the pattern of lipid deposition has shown little change. Notwithstanding, fatty acid profiles were markedly different between the 2 populations. Profiles for the coastal population were consistent with a diatom diet, particularly for females. In contrast, the Ace Lake population showed fatty acid profiles indicative of contributions from cryptomonads. Collectively, signature lipids have provided insight into the life cycle of $P$. antarctica, including dietary patterns.

Acknowledgements. We thank the expeditioners at Davis Station who helped with sampling throughout the year. We are grateful to T. Lewis for assisting with the fatty acid analyses, and to J. Cox for providing the map. Thanks to H. Burton, R. Seppelt and T. Bailey (Australian Antarctic Division) for the use of the Iatroscan and rotary evaporator. We thank 3 anonymous reviewers for their careful reading and constructive comments on the manuscript. This project was supported by the Australian Antarctic Science Advisory Committee (Project 691), the Ian Potter Foundation, the University of Tasmania and CSIRO Marine Research. The Australian Antarctic Division provided logistical support.

\section{LITERATURE CITED}

Atkinson A, Schnack-Schiel SB, Ward P, Marin V (1997) Regional differences in the life cycle of Calanoides acutus (Copepoda: Calanoida) within the Atlantic sector of the Southern Ocean. Mar Ecol Prog Ser 150:99-111

Bayly IAE (1978) The occurrence of Paralabidocera antarctica (I. C. Thompson) (Copepoda: Calanoida: Acartiidae) in an antarctic saline lake. Aust J Mar Freshw Res 29:817-824

Bayly IAE, Burton HR (1987) Vertical distribution of Paralabidocera antarctica (Copepoda: Calanoida) in Ace Lake, Antarctica, in summer. Aust J Mar Freshw Res 38:537-543

Bayly IAE, Eslake D (1989) Vertical distributions of a planktonic harpacticoid and a calanoid (Copepoda) in a meromictic Antarctic lake. Hydrobiologia 172:207-214

Bell EM, Laybourn-Parry J (1999) Annual plankton dynamics in an Antarctic saline lake. Freshw Biol 41:507-519

Burch MD (1988) Annual cycle of phytoplankton in Ace Lake, an ice covered, saline meromictic lake. Hydrobiologia 165:59-65

Dahms HU, Bergmans M, Schminke HK (1990) Distribution and adaptations of sea ice inhabiting Harpacticoida (Crustacea, Copepoda) of the Weddell Sea (Antarctica). PSZN I: Mar Ecol 11:207-226

Gibson JAE, Trull T (1999) Annual cycle of $f \mathrm{CO}_{2}$ under seaice and in open water in Prydz Bay, East Antarctica. Mar Chem 66:187-200

Gibson JAE, Swadling KM, Burton HR (1997a) Interannual variation in dominant phytoplankton species and biomass near Davis Station, East Antarctica. National Institute of Polar Research, Tokyo. Proc NIPR Symp Polar Biol 10: 78-90

Gibson JAE, Swadling KM, Pitman TM, Burton HR (1997b) Overwintering populations of Mesodinium rubrum (Ciliophora: Haptorida) in lakes of the Vestfold Hills, East Antarctica. Polar Biol 17:175-179

Hagen W, Kattner G, Graeve M (1993) Calanoides acutus and Calanus propinquus, Antarctic copepods with different storage modes via wax esters or triacylglycerols. Mar Ecol Prog Ser 97:135-142 
Hagen W, Kattner G, Graeve M (1995) On the lipid biochemistry of polar copepods: compositional differences in the Antarctic calanoids Euchaeta antarctica and Euchirella rostromagna. Mar Biol 123:451-457

Hagen W, Schnack-Schiel SB (1996) Seasonal lipid dynamics in dominant Antarctic copepods: energy for overwintering or reproduction? Deep-Sea Res 43:139-158

Hirche HJ, Kattner G (1993) Egg production and lipid content of Calanus glacialis in spring: indication of a food-dependent and food-independent reproductive mode. Mar Biol 117:615-622

Hopkins TL, Lancraft TM, Torres JJ, Donelly J (1993) Community structure and trophic ecology of zooplankton in the Scotia Sea marginal ice zone in winter (1988). Deep-Sea Res 40:81-105

Hoshiai T (1981) Proliferation of ice algae in the Syowa Station area, Antarctica. Mem Natl Inst Polar Res (Ser E: Biol Med Sci) 34:1-12

Hoshiai T, Tanimura A, Watanabe K (1987) Ice algae as food of an antarctic ice-associated copepod, Paralabidocera antarctica (I.C. Thompson). National Institute of Polar Research, Tokyo. Proc NIPR Symp Polar Biol 1:105-111

Kattner G, Graeve M, Hagen W (1994) Ontogenetic and seasonal changes in lipid and fatty acid/alcohol compositions of the dominant Antarctic copepods Calanus propinquus, Calanoides acutus and Rhincalanus gigas. Mar Biol 118: 637-644

Marshall SM, Orr AP (1955) The biology of a marine copepod, Calanus finmarchicus Gunnerus. Oliver \& Boyd, Edinburgh

Medlin LK, Lange M, Baumann MEM (1994) Genetic differentiation among three colony-forming species of Phaeocystis: further evidence for the phylogeny of the Prymnesiophyta. Phycologia 33:199-212

Nichols PD, Volkman JK, Palmisano AC, Smith GA, White DC (1988) Occurrence of an isoprenoid $C_{25}$ diunsaturated alkene and high neutral lipid content in Antarctic sea ice diatom communities. J Phycol 24:90-96

Nichols PD, Palmisano AC, Rayner MS, Smith GA, White DC (1989) Changes in the lipid composition of Antarctic seaice diatom communities during a spring bloom: an indication of community physiological status. Antarct Sci 1: 133-140

Nichols PD, Skerratt JH, Davidson A, Burton H, McMeekin TA (1991) Lipids of cultured Phaeocystis pouchetii: signatures for food-web, biogeochemical and environmental studies in Antarctica and the southern ocean. Phytochemistry 30:3209-3214

Palmisano AC, Lizotte MP, Smith GA, Nichols PD, White DC, Sullivan CW (1988) Changes in photosynthetic carbon assimilation in Antarctic sea-ice diatoms during spring bloom: variation in synthesis of lipid classes. J Exp Mar Biol Ecol 116:1-13

Phleger CF, Nichols PD, Virtue P (1998) Lipids and trophodynamics of Antarctic zooplankton. Comp Biochem Physiol 120B:311-323

Rankin LM, Gibson JAE, Franzmann PD, Burton HR (1999) The chemical stratification and microbial communities of

Editorial responsibility: Otto Kinne (Editor), Oldendorf/Luhe, Germany
Ace Lake, Antarctica: a review of the characteristics of a marine-derived meromictic lake. Polarforschung 66:35-52

Sargent JR, Henderson RJ (1986) Lipids. In: Corner EDS, O'Hara SCM (eds) The biological chemistry of marine copepods. Oxford Scientific Publications, Clarendon Press, Oxford, p 59-108

Schnack-Schiel SB, Thomas D, Dieckmann GS, Eicken H, Gradinger R, Spindler M, Weissenberger J, Mizdalski E, Beyer K (1995) Life cycle strategy of the Antarctic calanoid copepod Stephos longipes. Prog Oceanogr 36:45-75

Schnack-Schiel SB, Thomas D, Dahms H-U, Haas C, Mizdalski E (1998) Copepods in Antarctic sea ice. Antarctic sea ice biological processes, interactions, and variability. Antarct Res Ser 73:173-182

Skerratt JH, Nichols PD, McMeekin TA, Burton H (1995) Seasonal and inter-annual changes in planktonic biomass and community structure in eastern Antarctica using signature lipids. Mar Chem 51:93-113

Swadling KM (1998) Influence of seasonal ice formation on life cycle strategies of Antarctic copepods. PhD thesis, University of Tasmania, Hobart

Swadling KM, Gibson JAE, Ritz DA, Nichols PD (1997) Horizontal patchiness in sympagic organisms of the Antarctic fast ice. Antart Sci 9:399-406

Swadling KM, McPhee AD, McMinn A (2000) Spatial distribution of copepods in fast ice of eastern Antarctica. Polar Biosci 13:55-65

Tanimura A, Hoshiai T, Fukuchi M (1996) The life cycle strategy of the ice-associated copepod, Paralabidocera antarctica (Calanoida, Copepoda), at Syowa Station, Antarctica. Antarct Sci 8:257-266

Virtue P, Nichols PD, Nicol S, Hosie G (1996) Reproductive trade-off in male Antarctic krill, Euphausia superba. Mar Biol 126:521-527

Volkman JK, Nichols PD (1991) Applications of thin layer chromatography-flame ionization detection to the analysis of lipids and pollutants in marine and environmental samples. J Planar Chromat 4:19-26

Volkman JK, Burton HR, Everitt DA, Allen DI (1988) Pigment and lipid compositions of algal and bacterial communities in Ace Lake, Vestfold Hills, Antarctica. Hydrobiologia 165: $41-57$

Volkman JK, Jeffrey SW, Nichols PD, Rogers GI, Garland CD (1989) Fatty acid and lipid composition of 10 species of microalgae used in mariculture. J Exp Mar Biol Ecol 128: 219-240

Ward P, Shreeve RS, Cripps GC (1996) Rhincalanus gigas and Calanus simillimus: lipid storage patterns of two species of copepod in the seasonally ice-free zone of the Southern Ocean. J Plankton Res 18:1439-1454

White DC, Davis WM, Nickels JS, King JD, Bobbie RJ (1979) Determination of the sedimentary microbial biomass by extractable lipid phosphate. Oecologia 40:51-62

Wright SW, Burton HR (1981) The biology of Antarctic saline lakes. Hydrobiologia 82:319-338

Zwartz D, Bird M, Stone J, Lambeck K (1998) Holocene sealevel change and ice-sheet history in the Vestfold Hills, East Antarctica. Earth Planet Sci Lett 155:131-145

Submitted: February 28, 2000; Accepted: June 20, 2000

Proofs received from author(s): November 6, 2000 